\begin{tabular}{|c|c|c|} 
INTERNATIONAL JOURNAL OF \\
ORGACANIZATIONAL \\
IEADRSHIP
\end{tabular}

\title{
Equine-Assisted Experiential Learning on Leadership Development
}

\author{
Elif Bilginoğlu
}

Istanbul, Turkey

\begin{tabular}{|c|c|}
\hline & STRACT \\
\hline $\begin{array}{l}\text { Keywords: } \\
\text { Experiential learning, } \\
\text { Equine-assisted learning, } \\
\text { Human-horse interactions, } \\
\text { Leadership, Leadership } \\
\text { development }\end{array}$ & \multirow{6}{*}{$\begin{array}{l}\text { In today's fast-paced business world, where there is a need to develop divergent thinking and } \\
\text { a wider range of skills, organizations seek original ways to be successful. Accordingly, } \\
\text { leadership development has seen several uncommon approaches. Equine-assisted learning } \\
\text { programs which involve innovative, underutilized, and motivating techniques and strategies, } \\
\text { provide a dynamic process of building and developing leadership skills through horse-human } \\
\text { interactions. In this paper, after the history of horse-human relationships and interactions are } \\
\text { examined, a literature review is conducted on developing research and using equine-assisted } \\
\text { leadership development programs. Although the extant research shows that equine-assisted } \\
\text { leadership development programs promote skills critical to being an influential leader, the } \\
\text { present paper provides an insight into equine-assisted experiential learning on leadership } \\
\text { development, provides an overview on what happens in a typical equine-assisted experiential } \\
\text { learning session, and suggests practical implications for researchers and organizations. }\end{array}$} \\
\hline Received & \\
\hline 10 April 2021 & \\
\hline Received in revised & \\
\hline 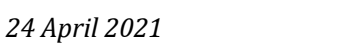 & \\
\hline & \\
\hline
\end{tabular}

26 April 2021

*Correspondence:

elifb@ada.net.tr

A human-horse relationship has a long history (Berg \& Causey, 2014; Hausberger, Roche, Henry \& Visser, 2008). Both ridden and driven horses became essential as pack animals, transportation sources and especially in military ventures. In this way, they have contributed to the success of humanity more than any other animal (Heleski, 2011; Kachelmeier, 2008). Over time, human use of horses has changed dramatically, and the horse's utilitarian value had decreased, whereas they have become equivalent in many ways to other domestic pets (Birke, Hockenhull, \& Creighton, 2010). Today horses still meet many human needs, including transportation, draft power, recreation, warfare, and companionship (Splan, 2011). While their 
muscle power is no longer required, another use of horses has attracted attention. Humans need their intuition and wisdom for the subtle challenges of mastering soft skills (Bjönberg, 2015), meaning they are now healers, teachers, and facilitators of learning (Pohl, 2012). While they used to feed humans physically by plowing their fields and socially by performing as race and show horses, today they feed humans mentally by working to engender skills that can be used as powerful instruments and facilitators for personal and leadership development (Maziere \& Gunnlaugson, 2015; Rauen, 2017).

Although the human-horse relationship goes back hundreds of years, the lessons learned from horses from a leadership, people skills, and communications perspective are only recently being taken into the business environment (Naidoo, 2009). In today's fast-paced business world, where there is a need to develop divergent thinking and a wider range of skills, organizations are looking for innovative ways to get ahead, and leadership development has seen several uncommon approaches (Gitsham, 2012; Rauen, 2017). Today, natural horsemanship, also referred to as "horse-whispering" is becoming in vogue in corporate leadership training and development worldwide (Naidoo, 2009). Accordingly, some of the world's largest organizations are discovering the unique lessons taught in equine-assisted courses. In addition, academics have acknowledged the value of working with horses at several university leadership development programs as a metaphor for leadership (Ridding, 2005). The literature on equine-assisted learning suggests that collaborating with horses can be a great example of learning leadership competencies. Besides, there has been explosive growth worldwide in this emerging industry (Dyk et al., 2012). This idea is unexpected and brings novelty and wonder with its aspects (Stock \& Kolb, 2016).

Throughout history, horses have been poised for greatness because of their anatomy, physiology, and sociability, and riding them has been associated with power (Equine Heritage Institute, 2013; Robinson, 1999). Thus, taking care of a horse has been essential for leaders for thousands of years; kings, wise men, and generals alike. As the word "manager" branches etymologically into the old French word "manege", which means "the handling or training of a horse, horsemanship, riding maneuvers, proceedings" (Clegg, Kornberger, \& Pitsis, 2008, p. 9; Kadalie, 2006, p. 19), the link between horses and the field of management was made long ago.

The ongoing discussions on how best to develop leaders assert that those who can harness intelligence in the body and brain have a distinct advantage in today's complex and volatile business environment (Cooper, 2000). Since horses are excellent examples to guide a learning process that facilitates this (Bjönberg, 2015), human experiences working with horses provide an opportunity to develop sustainable changes in an individual's awareness and actions regarding their leadership skills and authenticity (Gehrke, 2009; Lyle \& Schlamb, 2017). Thus, they are different from the traditional leadership training and development programs.

Dyk et al. (2012) claim that most research on equine-assisted interventions focuses on therapeutical studies, and academic research on the effectiveness of equine-assisted leadership development programs is scant. They add that more academic research should be conducted on this subject so that equine-assisted activities may gain credibility as legitimate learning and development methods for leaders. To fill this gap, the present paper attempts to offer a factual report on equine-assisted leadership development programs, which provide a unique method to build leadership and self-awareness skills through horse-human interactions. 


\section{Theoretical Background}

\section{Experiential Learning}

Adult learning theory encompasses more than just classroom teaching and places a premium on experiential learning (DeRosa, 2018; Lepsinger, 2018). Experiential learning is an active process that takes the learner out of their comfort zone and places them into a state of dissonance so that the learning may take place in an unfamiliar context. In this way, learning requires problem solving, inquiry, and reflection (Chapman, McPhee, \& Proudman, 1995; Martin, Franc, \& Zounková, 2016). It creates knowledge through the transformation of experience (Kolb, 2015: 51; Lewis \& Williams, 1994: 5), leading to unexpected discoveries (Rickards, 2000). More specifically, outdoor experiential learning takes learning and development out of the classroom setting and places it into the setting where knowledge may be built through social interaction in a genuine context (Kelly, 2019, p. 8). It is driven by process rather than content (Lewis \& Williams, 1994, p. 13).

It is asserted that leadership may be learned primarily through experience (McCall, 2004; Murphy \& Johnson, 2011). The more one participates, the more they will benefit from the opportunities for leadership growth (Propst \& Koesler, 1998). In this way, experiential learning theory provides a strong base for leadership education (Guthrie \& Jones, 2012). As equine experiences make an individual more sensitive to new ideas and behaviors (McCormick \& McCormick, 1997), and equine-assisted leadership development naturally integrates all levels of experience, the mind, emotions, spirit, and especially the body (Pohl, 2006), it is claimed that equine-assisted sessions find a basis in experiential learning model in a very practical sense (Rauen, 2017).

\section{The Origins of Guided Human Equine Interactions}

Horses and humans have a long history of interacting for mutual benefit (Notgrass \& Pettinelli, 2015). This includes emotional, psychological, and physical interactions. Research suggests that horses create a unique context for learning and their behavior and unique characteristics have major significance for experiential learning on leadership development (Gehrke, 2009; Hagen, 2007). They bring out a range of emotions and behaviors in humans, which can be used to stimulate personal awareness and growth (Zugich, Klontz, \& Leinart, 2002). Therewith the nature of the horse influences the nature of the leader (Rauen, 2017).

Horses preyed upon on food by wild animals and primitive men in the wild. As prey animals, their survival depends on their capability to be aware of their surroundings, to "read" the behaviors and intentions of predators, and react immediately to keep themselves safe. Since they know that they have to move away from what they perceive as dangerous for their safety, their first response to anything scary is flight (Evans, 2010; Keaveney, 2008; Sing, 2015). As flight animals by nature, they will not choose something less than a strong leader (Chappell, 2014).

As well as being prey animals, horses are environmentally sensitive and intuitive herd animals (Tinsley \& Jedlicka, 2012). While they depend on one another for survival, they rely most on their leader to see the real threat and react accordingly (Clinging, 2004). Therefore, the leadership of and throughout the herd is vital to ensure the survival of all (Rashid, 2011). Like a herd of horses, a team of people also requires strong leadership, effective communication, and 
a keen awareness of the needs and goals of the group (Roam Consulting, 2018). Accordingly, the characteristics of the herd leader, which are command, control, compassion, and communication (Hamilton, 2011), are similar to the characteristics of an effective leader (Chappell, 2014).

Horses have an extraordinary ability to identify a human's emotional state, intentions, and needs by reading their body language and mirroring the authentic feelings they try to hide (Gehrke, 2009; Kohanov, 2001). By this honest mirroring, they highlight behaviours that we may not yet be aware of and give us reliable feedback on our authenticity (de Beer, 2016; Notschaele, 2011). Since they react clear from socially desired behavior and high qualifications do not impact the horse's response to your presence (Frewin \& Gardiner, 2005; Grootveld, 2015; Hamilton, 2011; Mandrell, 2006), their responses during their interactions with humans are instinctive and instantaneous. As people often do not reject demands because of the real or perceived power that titles and consequences hold over them, leaders rarely receive such honest feedback as the horse provides (Chappell, 2014; Notgrass \& Pettinelli, 2015; Ridding, 2005).

Horses communicate nonverbally. They communicate mainly with body language and subtle signals. Humans primarily communicate verbally but also communicate with body language. In equine-assisted leadership development sessions, the participants learn to speak the language of the horses not only to understand what they are saying but also to tell them what they want them to know (Miller \& Lamb, 2005). In this way, they improve their consciousness of nonverbal communication (Maurstad, Davis, \& Cowles, 2013; Notschaele, 2011; Pohl, 2006; West, 2015) and their ability to interact and communicate with people (Wood, Gasser \& Winward, 2010). Effective communication using verbal and nonverbal communication has always been considered a critical part of successful leadership (Darioly \& Mast, 2014; Lac, 2017, p. 4; Marquis \& Huston, 2009, p. 461; Pichler \& Beenen, 2014, p. 11; Wülser, 2016).

\section{Equine-Assisted Experiential Learning on Leadership Development}

Equine-assisted learning (similarly referred to as equine-facilitated learning, equine-partnered learning, or equine-guided learning) (Lyle \& Schlamb, 2017; Strozzi Mazzucchi, 2015) is an experiential methodology that supports the development of life skills adaptable to educational, professional, or personal objectives through equine-assisted activities (Alm, 2018: 3). The workshops focus on solutions, and they are nondirective. They emphasize metaphoric content within human-horse interactions (Iwachiw, 2017; West, 2015), which can be transferred to several settings. They emphasize spiritual development, personal growth, and team-building to achieve more practical skills and success in the corporate environment (Burgon, 2014; Kelly, 2014, p. 219) through personal exploration of feelings and behaviors (Kohanov, 2001). The general areas within equine-assisted learning are education, leadership, or corporate and personal growth. A wide pool of professionals works in these three areas with participants to develop those life skills in a learning context (McKissock \& Anderson, 2018).

The participants who engage in a leadership development session may develop the skills necessary for effective leadership and learn new approaches to leadership or management (Hallberg, 2008). Since equine-assisted interventions are recently getting popular in the corporate world as a relatively new endeavor (DeSantis et al., 2017; Gunter, Berardinelli, Blakeney, Cronenwett, \& Gurvis, 2017; Hallberg, 2008; Pendry, Carr, Smith, \& Roeter, 2014), 
Horses play a joint coach role in leadership, team building, and personal development programs mong employees in several organizations (Gehrke, 2009).

It is suggested that out-of-class experiences can create a various positive learning and developmental outcomes (Mikulec \& McKinney, 2014). Experiential learning with horses deliberately takes participants outside their comfort positions, namely their offices, in an environment safe for experimentation. In this way, the participants become more open to selfdiscovery where they may view problems differently and get a clear understanding (Ewing, MacDonald, Taylor, \& Bowers, 2007; Gunter et al., 2017; Selby \& Smith-Osborne; 2013; Sing, 2015).

It is claimed that training in the outdoors seems to be emerging from the pack of notoriously diverse activities promoted by the unschooled, the unaccountable, and the unscrupulous (Thompson, 1991). Accordingly, the concept of using horses for leadership development might be regarded as a mere novelty, yet another fad or fashion in the corporate training field (Kelly, 2014; Stock \& Kolb, 2016). However previous research suggests that equine-assisted interventions provide the opportunity to foster the development of emotional intelligence (Bouchard, 2014; Dyk et al., 2012; Fransson, 2015; Gibbons, Cunningham, Paiz, Poelker, \& Chajón, 2017; Grootveld, 2015; Perkins, 2018; Rauen, 2017), development of life skills (Evans et al., 2009; Perkins, 2018; Slocum, 2004), social skills (Bouchard, 2014; Iwachiw, 2017), problem solving skills (Murphy, Wilson, \& Greenberg, 2017) and interpersonal skills (de Beer, 2016; Hesse \& Capitao, 2012), to build assertiveness (Fransson, 2015), social competence (Pendry et al., 2014), social-awareness (Rauen, 2017), perceived social support (Hauge, Kvalem, Berget, Enders-Slegers, \& Braastad, 2014), work ethic, time management, balance, collaboration, teamwork (de Beer, 2016; Duff, 2010; Mikulec \& McKinney, 2014), communication (de Beer, 2016; Mikulec \& McKinney, 2014; Murphy et al., 2017; Notschaele, 2011; Pentecost, 2017; Perkins, 2018; Saggers \& Strachan, 2016), self-awareness (Bouchard, 2014; de Beer, 2016; Grootveld, 2015; Notschaele, 2011; Rauen, 2017), self-efficacy (Bouchard, 2014); self-confidence (All, Loving \& Crane, 1999; Bouchard, 2014; de Beer, 2016; Perkins, 2018; Saggers \& Strachan, 2016), motivation (All et al., 1999; Pentecost, 2017), selfesteem, cooperation, enthusiasm (All et al., 1999), which are critical traits to being an influential leader. These findings verify that horse-assisted activities can help individuals develop leadership skills and thus contribute to leadership development. Previous research also suggests that participating in equine-assisted learning helps to teach leadership skills (Benson, 2012; Duff, 2010; Gibbons et al., 2017; Gunter et al., 2017; Kolzarek, 2001; Lyle \& Schlamb, 2017, Mikulec \& McKinney, 2014; Pohl, 2006; Ridding, 2005) and authentic leadership skills (Adams, 2013; Adams-Pope \& Stedman, 2014; Grootveld, 2015).

\section{An Equine-Assisted Experiential Learning Session}

Horses have been crucial and meaningful partners for humans throughout time. They have a unique ability to connect with humans. In addition, they react to their energy, strength, and perceptiveness (All et al., 1999; Kendall, Maujean, Pepping, \& Wright, 2014; Kuropatkin, 2013).

Equine-assisted experiential learning focuses on the learner's experience with the horses and promotes social, emotional, and cognitive development (Notgrass \& Pettinelli, 2015, p. 162; 
Murphy et al., 2017, p. 366). In addition, the workshops involve innovative and underutilized techniques to develop leadership skills (Saggers \& Strachan, 2016).

Horsemanship skills help the learner to interact with the horse and develop their approach to what works best for them in that situation (Prechter, 2014). However, equine-assisted learning is not a riding or horsemanship program. In the workshops, the participants may participate the care and handling of their partnered horse. While some programs incorporate riding the horse as part of the course (Ewing et al., 2007; Pentecost, 2017) by the majority of the programs, the emphasis is on non-mounted activities which create interactions between people and horses and require individuals or groups to catch and apply specific skills (Duff, 2010; Notgrass \& Pettinelli, 2015; Schulz, 2013).

Each session is unique to the participant(s). The number of sessions and the workshops' format will vary depending on the size, the objectives, and the time limitations of the participant group to find benefits. The sessions will be structured to allow participants to observe, perform the task and make changes correspondingly depending on their needs. After the participants arrive at a local equestrian facility, they are provided an orientation to their experience to get an overview of the agenda and processes they will experience in the session (Gunter et al., 2017; Pohl, 2006; Prechter, 2014; Rauen, 2017). Although the programs of the workshops are adaptable and flexible, a typical program includes topics such as getting acquainted with the horses, the basics of horsemanship, catching and leading horses, communication with the horses off the saddle, getting acquainted with the riding tack and equipment care, communication with the horse on the saddle, trust-building exercises, and working as a team including the horse (Saggers \& Strachan, 2016).

The horse professional, licensed educator, and the horse(s) make up the education team. The horse professional should have comprehensive experience working with the horses and understand their behaviors. They review the participants' basics of horse behavior related to its status as a prey and herd animal and teach them how to approach the horse before entering the arena. This review emphasizes self-observation, self-responsibility, and respect for the horse (Adams et al., 2015; Hagen, 2007; Rector, 2005). The licenced equine-assisted learning practitioners are educators, organizational consultants, corporate trainers, human resource professionals, and life coaches who incorporate horses into their work with clients (Green, 2017; Lac, 2017). The horses are viewed as joint facilitators of the workshop team, and they are allowed to respond naturally to events within the sessions (Iwachiw, 2017). They are usually semi-retired working horses which are very calm during their interactions with clients (Gehrke, Baldwin, \& Schiltz, 2011). During the sessions, while the facilitator monitors and processes the partipants' interactions with the horses, creating a reflective, experiential context for change, the participants gain new conceptions from the strong emotional experiences they come up with through these challenge activities (Green, 2017; Hagen, 2007; Lewis \& Williams, 1994). A professional who interprets how the horse's response mirrors the participants' thoughts, personality, and behavior is key to conducting efficient workshops. Therefore, their feedback is of critical importance (Maziere \& Gunnlaugson, 2015).

It is noted that equine-assisted interventions are not appropriate for everyone because of safety issues related to horses and the open environment in which the interventions occur (Bachi, 2012). As horses are large and powerful animals, their physical attributes and interactions sometimes inspire fear and trepidation or awe and excitement among participants 
(Notgrass \& Pettinelli, 2015). While some people find them intimidating, the practitioners should be aware of the comfort or anxiety of the participants and see if they can overcome the fear and work with an animal like this (Lac, 2017; Mandrell, 2006). In order to assure the safety and comfort of both the horses and the participants in a counseling session, the counselor should include horses that are calm and already physically, emotionally, and mentally pretty healthy and horses that the equine specialist knows well enough that he has a real sense of horses' druthers namely how they are likely response in any situation in the session (Hauge et al., 2014; Parelli \& Parelli, 2012). Accomplishing an equine-assisted task, despite those fears and being able to maneuver and control such a huge animal in size, creates confidence and provides for great metaphors when dealing with other intimidating and challenging situations in life (All et al., 1999; Kuropatkin, 2013; Mandrell, 2006; Vollmer, 2014).

\section{Conclusion}

This paper offers an introduction to the theoretical foundations of equine-assisted leadership development. This relatively new and increasingly popular approach provides a unique learning experience by incorporating human-animal interaction into educational settings. As a result, skills that can be difficult to acquire in more traditional settings are developed and enhance and complement leadership skills.

While the human-horse bond can enrich and inspire learning, the equine-assisted learning workshops allow the participants to view problems differently and get new sights. They help to revise the behaviors, cognitions, and unconscious processes. Although some people claim that drawing analogies between horse management and human leadership is dangerous (Rickards, 2000; Selby \& Smith-Osborne, 2013), the workshops obviously include all of the discussed processes in the leadership development literature, such as how goals are established, how decisions are made, who will make them and who will implement them as well as topics such as team development, conflict resolution, task management, communication, and relationships.

Previous research reveals that participants understand from their equine-assisted experience related to their style and organizational structure. Through the horses' modeling and teachings, they are encouraged to acquire new interpersonal skills and decide how better leaders should behave and treat others (Hagen, 2007; Hesse \& Capitao, 2012; West, 2015). Based on recent theoretical and empirical literature on equine-assisted learning, it can be claimed that working with horses can help to experience the power of the horse to teach critical life skills such as trust, respect, honesty, open communication, and to enhance a person's self-awareness. Previous research also provides evidence that the confidence developed through equestrian experiences makes leaders more eager to face difficulties and take on new challenges. The assertiveness learned through handling horses is useful in getting co-workers to accept the leadership (Fransson, 2015). In the workshops, participants experience and practice effective communication, willing partnership, shared vision, skillful action, and thoughtful decisionmaking (Naidoo, 2009). To sum up, corporating equine-assisted learning in a leadership development program may be a proven, highly effective, and rewarding way to hone or discover the skills critical to being an influential leader.

The findings of the present study are consistent with the claims of Pentecost (2017, p. 23) that horses are a natural model for leadership and with the claims of Lyle and Schlamb (2017, 
p. 4) that the human-horse relationship constitutes a creative exemplar that teaches leaders to be attentive to behaviours, needs, actions and reactions of those with whom they engage. Since the participation in the equine-assisted learning programs seem to have a primarily positive impact on teaching responsibility, caring, communicating as well as patience, empathy, trust, respect, confidence, attentiveness to others, conflict resolution through development in creative arts of persuasion, better communication skills (Keaveney, 2008), several emotional intelligence competencies (Grootveld, 2015), social skills, perceived sense of mastery, optimism, self-efficacy (Bouchard, 2014), self-awareness, self-confidence and team-building (Gehrke, 2009; Selby \& Smith-Osbourne, 2013), there is no doubt that the skills the leaders develop in equine-assisted programs impact an organization's bottom line.

Leadership development programs can be an organization's top tool to maintain a visionary, strong leadership team. Since they are critical to the long-term success of organizations, they constitute a competitive advantage (Fulmer \& Goldsmith, 2001; Weiss \& Molinaro, 2005). Organizations can maximize the impact and benefits of their leadership development programs by creating out-of-class learning opportunities. To this end, the present paper presents the case for a new framework for leadership development programs. Based on our extensive work and research in this field, the present paper shows that horses provide a strong metaphor for human leadership. Thus, by mindfully relating to a horse, leadership skills can be developed. Equineassisted leadership development programs constitute a unique, eye-opening, and profound leadership learning and development experience. Although the workshops may be relatively costly (Koris, Alalauri, \& Pihlak, 2017) and logistically difficult because they can only take place in rural and urban settings (Adams-Pope \& Stedman, 2014), they motivate the participants by offering a new environment, an unusual challenge, immediate feedback and chances to practice skills learned right away (Meola, 2016). The findings of the present study are consistent with the claims of Bjönberg (2015) that equine-assisted learning may be the next frontier in experiential leadership development. As Hagen (2007) claimed, very few leadership development programs can compete with this one for hands-on, experiential learning, and flatout-fun. The findings are also consistent with the claims of Felton (2012, p. 200) that they constitute an innovative way to bring a different perspective to leadership development programs while they are really effective and the return on investment is significant as personal breakthroughs can be achieved in minutes compares to months of traditional coaching.

It is recommended that equine-assisted leadership programs are offered to individuals who work in leadership positions. In addition, the universities that provide leadership training and development programs include equine-assisted leadership development workshops to their agenda.

It is crucial to note that the legitimacy of an equine-assisted learning program depends on the successful transfer of learning from the workshops on the farm to participant's personal and professional life (Dyk et al., 2012). To maximize results and improve future workshops, it is suggested that at the end of the workshop, the participants asses their own learning and evaluate the workshop to provide feedback to the facilitators. It is also suggested that a report is created which includes a summary of what learning goals are achieved from the workshop, the debrief notes from each session, noteworthy experiences that occurred, evaluation results, and next steps for development (Equine Experiential Education Association Marketing Committee, 2018). 
It should be recalled that there are discussions on equine-assisted leadership development that different management styles may lead to experiences of bullying and abusive behaviors. However, this helps the participants draw fine distinctions between being tough, being assertive, being supportive, and being soft (Rickards, 2000). Furthermore, since the equestrian community is shifting from fear-based leadership to respect-based leadership, the participants discover how the horses react as humans do to intimidating leaders (Kaplan, 2015).

Equine-assisted programs are beginning to find their way into the literature (Perkins, 2018, p. 299). However, despite the powerful anecdotal and descriptive evidence that supports the beneficial psychological outcomes associated with the use of horses as an integral part of a coaching session with humans, scientific research on this topic is scant (Andersen, 2009). The management has a crucial role in orientation to learning (Gutiérrez Gutiérrez, Bustinza, \& Barrales Molina, 2012). This paper is a road map for executives and human resources leaders considering how to develop leadership for competitive advantage, taking it more seriously and giving it the investment of time, money, and rigour that it deserves. The researcher hopes that the literature review and the recommendations compiled in this paper will stimulate further research on the effects of employing equine-assisted learning on leadership development.

\section{Limitations and Further Research}

This study represents an essential initial step in emphasizing the utility and value of equineassisted leadership development, a category of promising complementary practices that are still striving to prove their efficacy and validity (Brown, 2010; Kruger \& Serpell, 2010). As Jensen (2011) suggests, to allow the identification and elimination or revision of interventions that do not have the intended impact on self-awareness, formative evaluation of leader development programs is essential. Thus, the challenge for researchers in this area is to design both qualitative and quantitative studies that can examine whether equine-assisted activities can develop leadership skills and build an evidence-based to improve the potential application of equine-assisted leadership development programs. Another challenge for the researchers is to design studies that can examine whether the participants apply their learning in the context of their work environments. In sum, to improve equine-assisted leadership development, further studies must begin to focus on measuring the learning and transfer of leadership skills via equine-assisted interventions.

\section{References}

Adams, B. L. (2013). Using horses to teach authentic leadership skills to at-risk youth (Unpublished doctoral dissertation). The University of Florida.

Adams, C., Arratoon, C., Boucher, J., Cartier, G., Chalmers, D., Dell, C. A., Dell, D., Dryka, D., Duncan, R., Dunn, K., Hopkins, C., Longclaws, L. MacKinnon, T., Sauve, E., Spence, S., \& Wuttunee, M. (2015). The helping horse: How Equine assisted learning contributes to the wellbeing of first nations youth in treatment for volatile substance misuse. Human-Animal Interaction Bulletin, 1(1), 52-75.

Adams-Pope, B. L., \& Stedman, N. L. P. (2014). Horses and At-Risk Youth: An equine facilitated learning program focusing on authentic leadership skill development. Journal of Youth Development, 9(4). 
All, A. C., Loving, G. L., \& Crane, L. L. (1999). Animals, horseback riding and implications for rehabilitation therapy. The Journal of Rehabilitation, 65(3), 49-68.

Alm, K. (2018). Creating a learning environment. PATH International Strides, 24(2), 3.

Andersen, V. (2009). Equine guided coaching: A Critical exploration of the use of horses in coaching (Unpublished master's thesis). University of Portsmouth Business School, UK.

Bachi, K. (2012). Equine-facilitated psychotherapy: The gap between practice and knowledge. Society and Animals, 20(4), 364-380.

Benson, D. C. (2012). An exploration of the core dynamics of business leadership through the metaphor of equine herd leadership (Unpublished doctoral dissertation). Edinburgh Napier University.

Berg, E. L., \& Causey, A. (2014). The life-changing power of the horse: Equine-assisted activities and therapies in the U.S. Animal Frontiers, 4(3), 72-75.

Birke, L., Hockenhull, J., \& Creighton, E. (2010). The horse's tale: Narratives of caring for/about horses. Society and Animals, 18, 331-347.

Bjönberg, A. (2015, December 15). Why you need horse sense to develop leaders. Retrieved from https://ebhermanconsulting.com/wp-content/uploads/2016/05/Why-you-need-horse-sense-to-develop-leaders-chieflearning-officer-mag.pdf

Bouchard, M.V. (2014). "I just connect with the horses": Equine assisted learning as a tool for developing social skills and resiliency in at-risk youth (Unpublished master thesis). Queen's University. Kingston, Ontario, Canada.

Brown, K. (2010). Horses for discourses: The discursive construction of guided human equine interactions (Unpublished doctoral dissertation). The University of Southampton.

Burgon, H. L. (2014). Equine-assisted therapy and learning with at-risk young people. New York: Palgrave Macmillan.

Chapman, S., McPhee, P., \& Proudman, B. (1995). What is experiential education? In K. Warren (Ed.), The theory of experiential education (pp. 235-248). Dubuque: Kendall/Hunt Publishing Company.

Chappell, K. K. (2014). Equine-facilitated life coaching for youth leadership (Unpublished master thesis). Prescott College.

Clegg, S., Kornberger, M., \& Pitsis, T. (2008). Managing and organizations. London: Sage Publications.

Clinging, W. (2004, November). Do we need to dominate our horses? The Pacific and Prairie Horse Journal, 47-48.

Cooper, R.K. (2000). A new neuroscience of leadership: Bringing out more of the best in people. Strategy and Leadership, 28(6), 11-15.

Darioly, A., \& Mast, M.S. (2014). The role of nonverbal behavior in leadership: An integrative review. In R. E. Riggio \& S. J. Tan (Eds.), Leader interpersonal and influence skills: The soft skills of leadership (73-100). New York: Routledge.

de Beer, A. (2016). Influencing leadership skills, behaviour and values: An equine assisted leadership development course evaluation (Unpublished master thesis). Universiy of Pretoria.

DeRosa, D. (2018, May 11). 3 Leadership Development Trends to pay Attention to in 2018. Retrieved from https://www.onpointconsultingllc.com/blog/3-leadership-development-trends-to-pay-attention-to-in-2018

DeSantis, M., Contalbrigo, L., Borgi, M., Cirulli, F., Luzi, F., Redaelli, V., Stefani, A., Toson, M., Odore, R., Vercelli, C., Valle, E., \& Farina, L. (2017). Equine assisted interventions (EAIs): Methodological considerations for stress assessment in horses. Veterinary Sciences, 4(3), 1-14.

Duff, B. (2010). Learning with Horses enhances leadership at Source People. Training and Management Development Methods, 24(1), 301-305.

Dyk, P., Cheung, R., Pohl, L., Noriega, C., Lindgreen, J., \& Hayden, C. (2012). The effectiveness of equine guided leadership education to develop emotional intelligence in expert nurses: A pilot research study. University of Kentucky Center for Leadership Development, Lexington, Kentucky.

Equine Experiential Education Association Marketing Committee (2018). Best practices for delivering an equine-assisted learning workshop. PATH International Strides, 24(2), 25.

Equine Heritage Institute (2013). Shaping civilizations: The role of the horse in human societies. Retrieved from http://www.equineheritageinstitute.org/shaping-civilizations-the-role-of-the-horse-in-human-societies/

Evans, P. (2010). Equine Behavior: Prey vs. Predator, Horse vs. Human, Retrieved at http://digitallibrary.utah.gov/awweb/guest.jsp?smd=1\&cl=all_lib\&lb_document_id=40609

Evans, P. A., Jogan, K., Jack, N., Scott, A., Cavinder, C. A., McMillan, M., Gagnon, S., \& Waite, K. (2009). University Students may be better prepared for life after working with horses. NACTA Journal, 53(3), 37-43.

Ewing, C. A., MacDonald, P. M., Taylor, M., \& Bowers, M. J. (2007). Equine-facilitated learning for youths with severe emotional disorders: A quantitative and qualitative study. Child Youth Care Forum, 36, 59-72. 
Felton, J. (2012). Unbridled success: How the secret lives of horses can impact your leadership, teamwork and communication skills. UK: Ecademy Press.

Fransson, J. (2015). Leadership skills developed through horse experiences and their usefulness for business leaders (Unpublished project paper). Swedish University of Agricultural Sciences, Uppsala.

Frewin, K., Gardiner, B. (2005). New age or old sage? A review of equine assisted psychotheraphy. The Australian Journal of Counselling Psychology, 6, 13-17.

Fulmer, R. M., \& Goldsmith, M. (2001). The leadership investment: How the world's best organizations gain strategic advantage through leadership development. New York: Amacom.

Gehrke, E. K. (2009). Developing coherent leadership in partnership with horses: A new approach to leadership training. Journal of Research in Innovative Teaching, 2(1), 222-233.

Gehrke, E. K., Baldwin, A., \& Schiltz, P. M. (2011). Heart rate variability in horses engaged in equine-assisted activities. Journal of Equine Veterinary Science, 31(2), 78-84.

Gibbons, J. L., Cunningham, C. A., Paiz, L., Poelker, K. E., \& Chajón, A. (2017). Now, he will be the leader of the house': An equine intervention with at-risk Guatemalan youth, International Journal of Adolescence and Youth, 22(4), 390-404.

Gitsham, M. (2012). Experiential learning for leadership and sustainability at IBM and HSBC, The Journal of Management Development, 31(3), 298-307.

Green, S. (2017). Equine-assisted family theraphy. In J. Carlson \& S. B. Dermer (Eds.), The SAGE encyclopedia of marriage, family, and couples counseling (pp. 552-554). Thousand Oaks, California: Sage Publications.

Grootveld, N. N. (2015). Effective leadership: An explorative study to the active aspects of equine-assisted learning regarding to emotional intelligence (Unpublished master thesis). University of Twente, Enschede.

Gutiérrez Gutiérrez, L. J., Bustinza, O. F., \& Barrales Molina, V. (2012). Six sigma, absorptive capacity and organisational learning orientation. International Journal of Production Research, 50(3), 661-675.

Gunter, J., Berardinelli, P., Blakeney, B., Cronenwett, L., \& Gurvis, J. (2017). Working with horses to develop shared leadership skills for nursing executives. Organizational Dynamics, 46(1), 57-63.

Guthrie, K. L., \& Jones, T. B. (2012). Teaching and learning: Using experiential learning and reflection for leadership education. New Directions for Student Services, 140, 53-63.

Hagen, J. W. (2007). An equine-assisted model for developing effective leadership. John Ben Shepperd Journal of Practical Leadership, 1-6.

Hallberg, L. (2008). Walking the way of the horse: Exploring the power of the horse-human relationship. USA: iUniverse.

Hamilton, A. J. (2011). Zen mind Zen horse: The science and spirituality of working with horses. North Adams, MA: Storey Publishing.

Hauge, H., Kvalem, I. L., Berget, B., Enders-Slegers, M. J., \& Braastad, B. O. (2014). Equine-assisted activities and the impact on perceived social support, self-esteem and self-efficacy among adolescents - An intervention study. International Journal of Adolescence and Youth, 19(1), 1-21.

Hausberger, M., Roche, H., Henry, S., \& Visser, E. K. (2008). A review of the human-horse relationship. Applied Animal Behaviour Science, 109(1), 1-24.

Heleski, C. (2011). Horses: Human interactions. In W. G. Pond, D. E. Ullrey, \& C. K. Baer (Eds.), Encyclopedia of animal science (pp. 629-631). Boca Raton, FL: Taylor \& Francis.

Hesse, U., \& Capitao, C. G. (2012). Horse-based personal development: Innovative methods for corporative context. Congress of Therapeutic Horse Ridding Proceedings, 24-27 April 2012.

Iwachiw, J.S. (2017). A powerful approach or the power of horses: Is equine-assisted psychotherapy an effective technique or the natural effect of horses? (Unpublished doctoral dissertation). Alfred University Division of Counseling and School Psychology, Alfred, NY.

Jensen, M. L. (2011). Nurturing self-knowledge: The impact of a leadership development program. OD Practitioner, 43(3), $30-35$.

Kachelmeier, P. A. (2008). Starting an equine-assisted program: An investigative study into the creation of an equine assisted psychotherapy or learning business (Unpublished master thesis). Prescott College.

Kadalie, D. (2006). Leader's resource kit: Tools and techniques to develop your leadership. Nairobi, Kenya: Evangel Publishing House.

Kaplan, M. D. G. (2015, January 06). What horses can teach us about leadership. Retrieved from http://fortune.com/2015/01/06/salamander-resort-horses/

Keaveney, S. M. (2008). Equines and their human companions. Journal of Business Research, 61(5), 444-454. 
Kelly, S. (2014). Horses for courses: Exploring the limits of leadership development through equine-assisted learning. Journal of Management Education, 38(2), 216-233.

Kelly, R. (2019). Constructing leadership 4.0: Swarm leadership and the fourth industrial revolution. Switzerland: Palgrave Macmillan.

Kendall, E., Maujean, A., Pepping, C. A., \& Wright, J. J. (2014). Hypotheses about the psychological benefits of horses. Explore, 10(2), 81-87.

Kohanov, L. (2001). The tao of equus: A woman's journey of healing and transformation through the way of the horse. Novato, California: New World Library.

Kolb, D. A. (2015). Experiential learning: Experience as the source of learning and development. New Jersey: Pearson Education.

Kolzarek, B. (2001). Führen lernen mit Pferden? Überprüfung eines Seminarkonzeptes für Führungskräfte [Learning to lead with horses? Review of a seminar concept for managers] (Unpublished master thesis). Technischen Universität Dortmund.

Koris, R., Alalauri, H. M., \& Pihlak, Ü. (2017). Learning leadership from horseback riding - more than meets the eye. Development and Learning in Organizations, 31(3), 11-14.

Kruger, K. A., \& Serpell, J. A. (2010). Animal-assisted interventions in mental health: Definitions and theoretical foundations. In A. Fine (Ed.), Handbook on animal-assisted therapy (pp. 17-32). New York: Academic Press.

Kuropatkin, L. (2013). The benefits of equine-assisted activities and therapies. EP Magazine, 32-34.

Lac, V. (2017). Equine-facilitated psychotherapy and learning: The human-equine relational development (HERD) approach. UK: Elsevier.

Lepsinger, R. (2018, January 02). What's missing in leadership development programs today? Retrieved from https://www.onpointconsultingllc.com/blog/whats-missing-in-leadership-development-programs-today

Lewis, L. H., \& Williams, C. J. (1994). Experiential learning: Past and present. In L. Jackson \& R. S. Caffarella (Eds.), Experiential learning: A new approach (pp. 5-16). San Francisco: Jossey-Bass.

Lyle, E., \& Schlamb, C. (2017). Leadership of another kind: What equine-partnered experience can teach us about leading. Pathways - The Ontario Journal of Outdoor Education, 29(4), 4-13.

Mandrell, P. J. (2006). Introduction to equine-assisted psychotheraphy. USA: Xulon Press.

Marquis, B. L., \& Huston, C. J. (2009). Leadership roles and management functions in nursing: Theory and application. Philadelphia: Wolters Kluwer.

Martin, A., Franc, D., \& Zounková, D. (2016). Outdoor and experiential learning: An holistic and creative approach to programme design. New York: Routledge.

Maurstad, A., Davis, D., \& Cowles, S. (2013). Co-being \& intra-action in horse-human relationships: A multi-species ethnography of becoming human and becoming horse. Social Anthropology, 21(3), 322-335.

Maziere, C., \& Gunnlaugson, O. (2015). A case for developing spiritual intelligence in leaders through equine facilitated learning, The Journal of Values-Based Leadership, 8(1), Article 10, 1-17

McCall, M. W. (2004). Leadership development through experience. Academy of Management Executive, 18(3), 127-130.

McCormick, A. V., \& McCormick, M. D. (1997). Horse sense and the human heart. Deerfield Beach, FL: Health Communications.

McKissock, B., \& Anderson, D. (2018). Past, present and future of EAL. PATH International Strides, 24(2), 16-21.

Meola, C. C. (2016). Addressing the needs of the millennial workforce through equine assisted learning. Journal of Management Development, 35(3), 294-303.

Mikulec, E., \& McKinney, K. (2014). Perceived learning outcomes from participation in one type of registered student organization: Equestrian sport clubs. Journal of the Scholarship of Teaching and Learning, 14(3), 93-109.

Miller, R. M., \& Lamb, R. (2005). The revolution in horsemanship: And what it means to mankind. Guilford, Connecticut: The Lyons Press.

Murphy, S. E., \& Johnson, S. K. (2011). Leadership research and education: How business schools approach the concept of leadership. In R. E. Riggio \& M. Harvey (Eds.), Leadership studies: The dialogue of disciplines (pp. 129-148). Cheltenham, UK: Edward Elgar.

Murphy, L., Wilson, J., \& Greenberg, S. (2017). Equine-assisted experiential learning in occupational theraphy education. Journal of Experiential Education, 40(4), 366-376.

Naidoo, S. (2009, February 04). Learning leadership from horses. The Mercury.

Notgrass, C. G., \& Pettinelli, J. D. (2015). Equine assisted psychotheraphy: The equine asissted growth and learning association's model overview of equine-based modalities. Journal of Experiential Education, 38(2), 162-174. 
Notschaele, I. R. (2011). Increasing consciousness of nonverbal communication with equine-assisted leadership training (EALT): An exploratory study (Unpublished master's thesis). University of Twente.

Parelli, P., \& Parelli, L. (2012). Looking at equine assisted counseling from the horse's perspective. In K. S. Trotter (Ed.), Harnessing the power of equine assisted counseling: Adding animal assisted therapy to your practice (pp. 17-26). New York: Routledge.

Pendry, P., Carr, A. M., Smith, A. N., \& Roeter, S. M. (2014). Improving adolescent social competence and behavior: A randomized tiral of an 11-week equine faciliated learning prevention program. The Journal of Primary Prevention, 35, 281-293.

Pentecost, L. A. (2017). The effects of equine assisted leadership programs on perceived professional development outcomes (Unpublished doctoral dissertation). Liberty University, Lynchbur, Virginia.

Perkins, B. L. (2018). A pilot study assessing the effectiveness of equine-assisted learning with adolescents. Journal of Creativity in Mental Health, 13(3), 298-305.

Pichler, S., \& Beenen, G. (2014). Toward the development of a model and a measure of managerial interpersonal skills. In R. E. Riggio \& S. J. Tan (Eds.), Leader interpersonal and influence skills: The Soft Skills of Leadership (pp. 11-30). New York: Routledge.

Pohl, L. (2006). Equine guided leadership education: Putting physical intelligence back in learning leadership competencies. University of Kentucky Center for Leadership Development, Lexington, Kentucky.

Pohl, L. (2012). Crossing the great leadership competency divide with horse as guide. Transformative Learning Conference San Francisco, CA 2012.

Prechter, A. K. (2014). An assessment of equine assisted growth learning association and professional association of therapeutic horsemanship programs in Montana (Unpublished master thesis). Montana State University, Bozeman, Montana.

Propst, D. B., \& Koesler, R. A. (1998). Bandura goes outdoors: Role of self-efficacy in the outdoor leadership development process. Leisure Sciences, 20(4), 319-344.

Rashid, M. (2011). Horses never lie: The heart of passive leadership. New York: Sky Horse Publishing.

Rauen, J. E. (2017). The effectiveness of equine assisted learning on emotional intelligence and leadership skills (Honors theses, 490), Eastern Kentucky University.

Rector, B. K. (2005). Adventures in awareness: Learning with the help of horses. Bloomington, Indiana: AuthorHouse.

Rickards, T. (2000). Trust-based leadership: Creative lessons from intelligent horsemanship. Creativity and Innovation Management, 9(4), 259-266.

Ridding, K. J. E. (2005). A natural approach: Leadership in horses as a model for leadership in organizations (Unpublished master's thesis). Royal Roads University.

Roam Consulting (2018). Leadership development with horses. Retrieved from https://roamconsultingllc.com/leadershipwith-horses/

Robinson, I. H. (1999). The human-horse Relationship: How much do we know? Equine Veterinary Journal, 31(28), $42-45$.

Saggers, B., \& Strachan, J. (2016). Horsing around: Using equine facilitated learning to support the development of socialemotional competence of students at risk of school failure, Child and Youth Services, 37(3), 231-252.

Schulz, A. (2013, January 19). Wie Pferde Managern das Führen beibringen [How horses teach managers to lead]. Retrieved from https://www.welt.de/regionales/hamburg/article112865235/Wie-Pferde-Managern-das-Fuehren-beibringen.html

Selby, A., \& Smith-Osborne, A. (2013). A systematic review of effectiveness of complementary and adjunct therapies and interventions involving equines. Health Psychology, 32(4), 418-432.

Sing, Y. (2015). Transforming people: From the paddock to the boardroom. Flashes, 34-37.

Slocum, S. S. (2004). A comparison of leadership life skills development of youth participating in riding and non-riding competitive 4-H horse events in Mississippi (Unpublished doctoral dissertation). Mississippi State University.

Splan, R. K. (2011). Horses: Breeds, breeding, and genetics. In W. G., Pond, D. E., \& Ullrey \& C. K. Baer (Eds.), Encyclopedia of animal science (pp. 626-628). Boca Raton, FL: Taylor \& Francis.

Stock, K. L., \& Kolb, D. A. (2016). Equine-assisted experiential learning. OD Practitioner, 43-47.

Strozzi Mazzucchi, A. (2015). Equine guided education: Horses healing humans healing earth. USA: CreateSpace Independent Publishing Platform.

Thompson, B. L. (1991). Training in the great outdoors. Training, 28(5), 46-52. 
Tinsley, K. A., \& Jedlicka, H. (2012). Equine assisted counseling with deaf families. In K. S. Trotter (Ed.), Harnessing the power of equine assisted counseling: Adding animal assisted therapy to your practice (pp. 165-179). New York: Routledge.

Vollmer, J. (2014, June 25). Was manager auf dem Rücken von Pferden lernen [What managers learn on horseback].

Retrieved from https://www.handelszeitung.ch/management/was-manager-auf-dem-ruecken-von-pferden-lernen630974\#

Weiss, D. S., \& Molinaro, V. (2005). The leadership gap: Building leadership capacity for competitive advantage. Canada: John Wiley \& Sons.

West, R. A. (2015). The silent language of emotions: Equine inspired leadership development (Unpublished doctoral dissertation). Wilmington University.

Wood, L. G., Gasser, C. L., \& Winward, D. L. (2010). Perceptions of the impact of an equine program on student satisfaction and retention. Nacta Journal, 54(1), 17-20.

Wülser, T. (2016, Juli 07). Leadership - Wenn einem das Pferd den Spiegel vorhält [Leadership - When the horse holds the mirror up to somebody]. Retrieved from https://www.lid.ch/medien/dossier/detail/info/artikel/leadership-wenn-einemdas-pferd-den-spiegel-vorhaelt/

Zugich, M., Klontz, T., \& Leinart, D. (2002). The miracle of equine therapy. Counselor Magazine, 3(6), 22-27.

\section{Acknowledgments}

Not applicable.

\section{Disclosure Statement}

No potential conflict of interest was reported by the authors.

\section{Funding Acknowledgments}

Not applicable.

\section{Open Access}

The International Journal of Organizational Leadership publishes open access articles under the terms of the Creative Commons Attribution (CC BY) License, which permits use, distribution, and reproduction in any medium, provided the original work is properly cited. 